T. Korytko ${ }^{1}$ orcid.org/0000-0002-4251-1971,

I. Bryl ${ }^{1}$, orcid.org/0000-0003-1526-0094, S. Piletska ${ }^{2}$, orcid.org/0000-0002-3638-3002, O. Arefieva ${ }^{2}$, orcid.org/0000-0001-5157-9970, S. Arefiev ${ }^{3}$, orcid.org/0000-0003-2184-458X
1 - Institute of Industrial Economics of the National Academy of Sciences of Ukraine, Kyiv, Ukraine, e-mail: taniakorytko@ gmail.com

2 - National Aviation University, Kyiv, Ukraine

3 - National University of Technologies and Design, Kyiv, Ukraine

\title{
STRATEGY OF INNOVATIVE DEVELOPMENT OF AN ENTERPRISE ON THE BASIS OF EVALUATION OF ITS INTELLECTUAL CAPITAL
}

Purpose. Improvement of strategy of industrial enterprises' innovative development on the basis of an estimation of the enterprise's intellectual capital and development of the stages of a choice of strategy using hierarchy analysis method.

Methodology. The study used a set of general and special methods of cognition: content analysis, logical generalization, quantitative and qualitative comparison, the method of principal components, and systematization.

Findings. The suggested assessment of intellectual capital of the enterprise and the methodological approach to the formation and selection of strategies for innovative development in terms of its digitalization allows analyzing quantitative indicators of structural elements of intellectual capital and determining the state and level of development of each element. This makes it possible to increase the efficiency of the formation and implementation of the strategy of innovative development of the enterprise.

Originality. In the course of the research, the algorithm of integrated estimation of intellectual capital of industrial enterprises has been developed. It allowed assessing the level of intellectual capital, stages of formation of innovative development strategy, which act as an information-analytical tool for the development of options for strategic development of industrial enterprises. A model for implementing an innovative strategy for the development of industrial enterprises provides a choice of innovative strategy for the development of industrial enterprises. The method of analysis of hierarchies allowed identifying the most receptive innovation strategies to industrial enterprises.

Practical value. The results of the study can be used by practitioners, scientists, civil servants (Ministry of Economic Development, Trade and Agriculture and its structural units, local governments in the field of economics) to develop and implement innovation strategies, as well as to develop measures to promote sustainable development in the area of innovation, increasing its intellectual capital, value added, capitalization and level of competitiveness.

Keywords: industrial enterprise, innovation development, intellectual capital, digitalization

Introduction. The digital economy has a great influence on production, trade, transport and financial services, education, health care, the media and others. Technologies expand the capabilities of people and businesses in various areas, provide the opportunity to create and disseminate ideas, develop and implement innovations in business.

Thus, this study has an interdisciplinary aspect, as digital transformation requires the creation of a scientific knowledge base for the formation of a strategy for innovative development of the enterprise based on the assessment of innovative capital.

Literature review. In today's economic environment, intellectualization management is an integral part of the innovation management process and solves the issues of planning and implementation of innovative strategies for sustainable development of an enterprise. The growth of innovative development strategies in the context of intellectualization is based on the assessment of intellectual capital.

The scientific research [1] examines the stages of development of digital transformations and notes that digital transformation has certain consequences in changing the indicators used in assessment of efficiency. Research on strategic management $[2,3]$ is aimed at conceptualizing and updating business processes. According to [4, 5] the impact of digitalization on innovation is not clear enough, and the use of technological opportunities, including in determining the directions of formation of innovation strategies is a rather difficult task. Research related to information systems is aimed at implementing technological developments related to the use of digital technologies and the benefits for business that have arisen [6].

(C) Korytko T., Bryl I., Piletska S., Arefieva O., Arefiev S., 2021
The intellectual potential of the e-economy is a comprehensive indicator that directly affects the development of modern society, including the formation of so-called "digital capital”.

Methods for measuring intellectual capital are being developed to improve the understanding of all intangible assets, as well as to form a theory to explain the identification of these assets and assess the value of the enterprise [7]. In a more systematic form, the structure of intellectual capital includes human capital; structural capital; client capital [8, 9]. At the same time some scientists $[10,11]$ note that the structure of intellectual capital consists of human and technological capital. The peculiarity of intellectual capital $[12,13]$ is that it does not lose its value over time, and even increases it, while equipment and technology begin to depreciate from the moment of their acquisition. An essential component of intellectualization is intellectual capital, which in turn includes: human, client or business capital, organizational, innovation, process and market capital $[14,15]$. But it should be noted that without human capital, there can be no intellectual capital, between them the existence of mutual direct and feedback is confirmed.

The subject of the work is related to the argumentation of the methodical approach to the formation and selection of the strategy of innovative development based on the assessment of intellectual capital in the context of digitalization. The author's approach to solving this problem is substantiated in the article.

Unsolved aspects of the problem. At the same time, some issues remain unresolved and require additional research, development of an integrated assessment of the intellectual capital of machine-building enterprises and tools for choosing a strategy for innovative development. The subject of the study is the indicators that underlie the assessment of intellectual capi- 
tal and the choice of strategy for innovative development of the enterprise. The object of research includes theoretical, practical and methodological aspects of formation and choice of strategy of innovative development of the enterprise in the conditions of digitalization.

The purpose of the article is to form a strategy for innovative development of machine-building enterprises based on the assessment of intellectual capital of the enterprise and to develop stages of the strategy selection process based on the method of hierarchy analysis.

Methods. The choice of an innovative strategy for the development of a machine-building enterprise in terms of intel- lectualization is based on the calculation of the integrated coefficient of intellectual capital valuation.

It is suggested evaluating intellectual capital based on the use of structural (element-by-element) approach as a set of components, based on the evaluation of its individual components, followed by their summation for general evaluation (mainly cost methods) [16].

Based on the study on approaches to the assessment of intellectual capital, the following algorithm is suggested (Fig. 1).

Based on the use of the expert assessment procedure, a system of indicators for assessing the intellectual capital of machine-building enterprises is formed (Table 1).

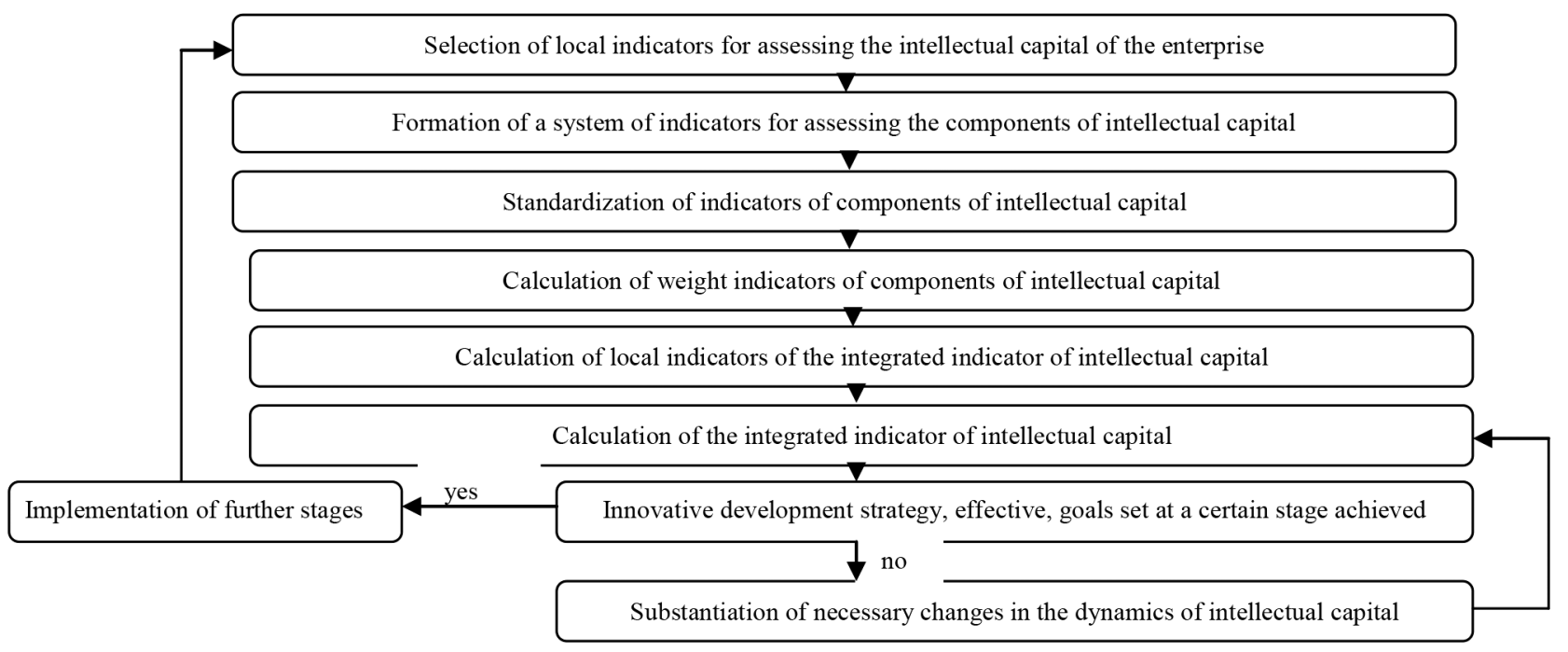

Fig. 1. Algorithm for integrated assessment of intellectual capital of machine-building enterprises

Table 1

Indicators of intellectual capital of machine-building enterprises

\begin{tabular}{|c|c|c|}
\hline $\begin{array}{l}\text { Components of } \\
\text { intellectual capital }\end{array}$ & Indicators & Calculation formula \\
\hline \multirow[t]{4}{*}{$\begin{array}{l}\text { Human capital } \\
\text { (Ihc) }\end{array}$} & Staff turnover ratio $(\mathrm{X} 1)$ & $\begin{array}{l}\mathrm{X} 1=\mathrm{EmpDis} / \mathrm{EmpAv} \\
\text { where EmpDis is the number of dismissed employees for a certain period; } \\
\text { EmpAv is the average number of full-time employees of the payroll }\end{array}$ \\
\hline & $\begin{array}{l}\text { The share of wage costs in the operating } \\
\text { costs of the enterprise (X2) }\end{array}$ & $\begin{array}{l}\mathrm{X} 2=\mathrm{WC} / \mathrm{OCE} \text {, } \\
\text { where WC is wage costs; OCE is operating costs of the enterprise }\end{array}$ \\
\hline & $\begin{array}{l}\text { The share of workers with university } \\
\text { degrees in the average number of } \\
\text { employees of the enterprise (X3) }\end{array}$ & $\begin{array}{l}\mathrm{X} 3=\mathrm{EmpHE} / \mathrm{EmpAv}, \\
\text { where EmpHE is the number of employees with university degrees }\end{array}$ \\
\hline & Employee Development Index (X4) & $\begin{array}{l}\qquad \mathrm{X} 4=\text { Pers retr/Pers, } \\
\text { where EmpRetr is the number of employees who have undergone retraining, pers }\end{array}$ \\
\hline \multirow[t]{4}{*}{$\begin{array}{l}\text { Organizational } \\
\text { capital (Ioc) }\end{array}$} & Personnel stability index (X5) & $\begin{array}{l}\mathrm{X} 5=1-\text { (EDis/pers), } \\
\text { where EDis is the number of dismissed employees, pers }\end{array}$ \\
\hline & $\begin{array}{l}\text { Coefficient of research intensity (R\&D) } \\
\text { (X6) }\end{array}$ & $\begin{array}{l}\mathrm{X} 6=\text { Br.d./Bo.o.c.e, } \\
\text { where Br.d. is costs; Bo.o.c.e is other operating costs of the enterprise }\end{array}$ \\
\hline & Coefficient of intellectual intensity (X7) & $\begin{array}{l}\mathrm{X7}=\mathrm{ItA} / \mathrm{RS}, \\
\text { where ItA is the value of intangible assets; RS is revenue from sales }\end{array}$ \\
\hline & Computer service factor $(\mathrm{X} 8)$ & $\begin{array}{l}\qquad \mathrm{X} 8=\mathrm{PC} \mathrm{SA} \\
\text { where PC is the number of personal computers in the enterprise; SA is the } \\
\text { number of system administrators }\end{array}$ \\
\hline \multirow{3}{*}{$\begin{array}{l}\text { Consumer capital } \\
\text { (Icc) }\end{array}$} & Number of signed contracts (X9) & - \\
\hline & Market share (X10) & - \\
\hline & Product Competitiveness Index (X11) & $\begin{array}{l}\mathrm{X} 11=0.35 \mathrm{Ent} \mathrm{Ef}+0.30 \mathrm{FEnt}+0.35 \mathrm{Ec} \\
\text { Ent Ef is the value of the criterion of efficiency of production activities of the } \\
\text { enterprise; FEnt is the value of the criterion of the financial position of the } \\
\text { enterprise; Ec is the value of the criterion of the effectiveness of the organiza- } \\
\text { tion of sales and promotion of goods on the market }\end{array}$ \\
\hline
\end{tabular}


That is, having determined the necessary assessment indicators for the calculation of the integrated coefficient of assessment of intellectual capital of the enterprise [17], we suggest using the geometric mean of the assessments of its components by the formula

$$
I_{i c}=\sqrt[3]{I_{h c} \times I_{o c} \times I_{s c}},
$$

where $I_{h c}, I_{o c}, I_{s c}$ are integral coefficients of assessment of human, structural and organizational capital relations, respectively.

To ensure comparability, we ration the indicators in the range $[0 ; 1]$.

For indicators, the minimum value of which is the best rationing is carried out using the following formula

$$
K_{i}=\frac{K_{\max }-K_{i}(x)}{K_{\max }-K_{\min }},
$$

where $K_{i}$ is normalized indicator; $K_{i}(x)$ is the average (actual) value of the indicator; $K_{\max }$ is the maximum value of the indicator; $K_{\min }$ is the minimum value of the indicator; $i=1, n$.

For indicators, the maximum value of which is the best, rationing is carried out using the following formula

$$
K_{i}=\frac{K_{i}(x)-K_{\max }}{K_{\max }-K_{\min }} .
$$

The following integral coefficients are calculated by the formula

$$
I_{h c(o c, s c)}=\sum_{j=1}^{n} I_{j} \times Y_{j},
$$

where $n$ is number of indicators; $I_{j}$ is the value of the indicator; $Y_{j}$ is the coefficient of specific weight of the indicator.

The values of the indicators included in the suggested system of assessment of intellectual capital of machine-building enterprises are in the range from 0 to 1 , and the more efficient the enterprise, the closer the value of the indicator to 1 .

In order to choose the innovative strategy of machinebuilding enterprises, a model of construction and substantiation of the choice of innovative strategy of enterprise development aimed at increasing its level of intellectualization is suggested [18, 19]. The stages of formation of the innovative strategy of development of the machine-building enterprise in the conditions of intellectualization are given in Fig. 2.

The suggested model is an information-and-analytical tool for developing options for strategic growth of machinebuilding enterprises.

Table 2 provides recommendations for choosing a strategy for innovative growth of the enterprise depending on the results of the assessment of intellectual capital. Characteristics of innovative growth depending on the value of the integrated indicator of intellectual capital are given in Table 2.

Depending on the results of the evaluation of the values of a single integrated indicator of intellectual capital, the choice of innovation growth strategy is made. The use of the suggested approach to determine the value of the integrated indicator of intellectual capital of machine-building enterprises allows one to choose a strategy and identify problems in implementing an innovative growth strategy, taking into account the attractiveness of the innovation environment.

Thus, it should be noted that the implementation of innovation strategy, development of machine-building enterprises is carried out in stages and is a multi-step process of development and mutual coordination of local strategies.

The mechanism for ensuring the choice of innovative strategy for the development of machine-building enterprises is a certain algorithm, which includes procedures for the formation of information base, collection, processing and use of information on the activities of machine-building enterprises. The model of implementation of the innovative strategy of growth of machine-building enterprises by stages is shown in Fig. 3 .

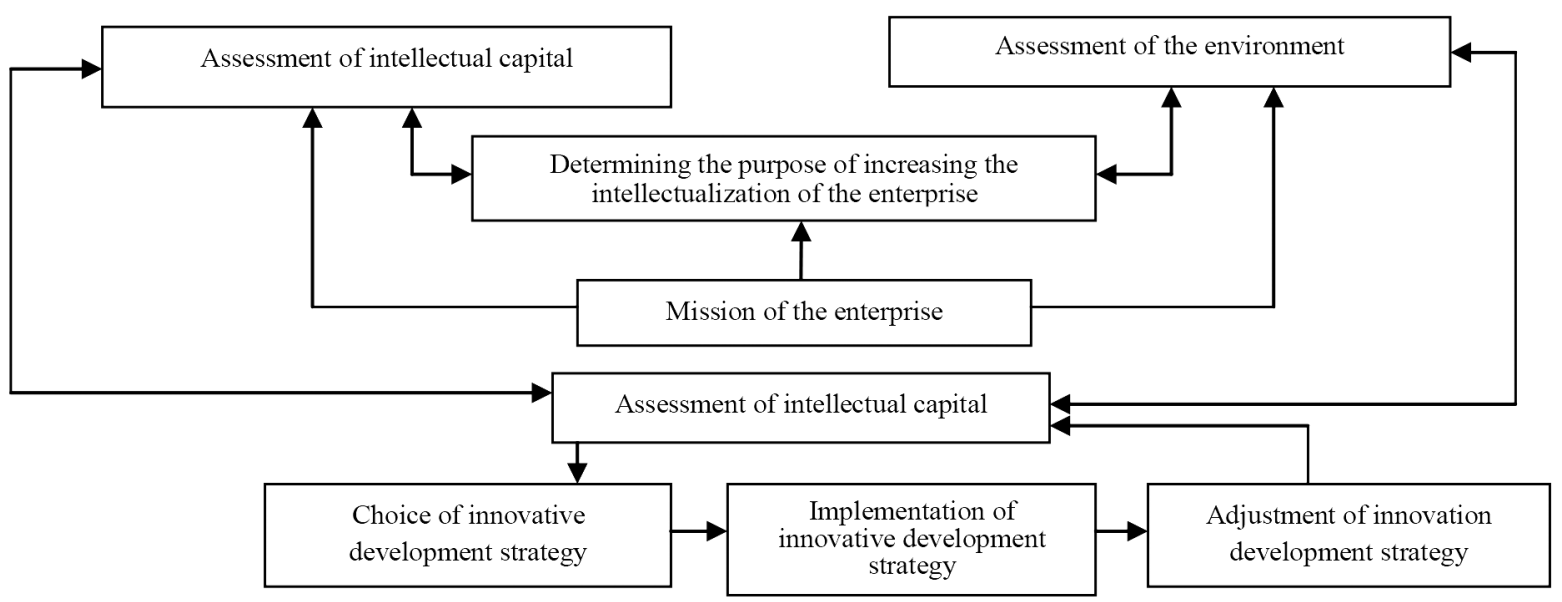

Fig. 2. Stages of formation of innovative strategy of development of a machine-building enterprise in the conditions of intellectualization

Table 2

Characteristics of innovation growth from the value of the integrated index of intellectual capital of machine-building enterprises on the basis of the modified Harrington scale

\begin{tabular}{|l|c|l|}
\hline $\begin{array}{c}\text { Characteristics of the level of intellectual } \\
\text { capital of enterprises }\end{array}$ & $\begin{array}{c}\text { The value of the integrated indicator of the } \\
\text { level of intellectual capital of enterprises }\end{array}$ & $\begin{array}{l}\text { Recommended options for management decisions on the } \\
\text { choice of strategy for innovative growth of the enterprise }\end{array}$ \\
\hline Rapid growth of intellectual capital & $0.8-1$ & Expansion strategy \\
\hline Moderate growth of intellectual capital & $0.63-0.8$ & Upgrade strategy \\
\hline Slow growth of intellectual capital & $0.37-0.63$ & Development strategy \\
\hline Low growth of intellectual capital & $0.2-0.37$ & Reorganization strategy \\
\hline Lack of intellectual capital growth & $0-0.2$ & Business downsizing \\
\hline
\end{tabular}




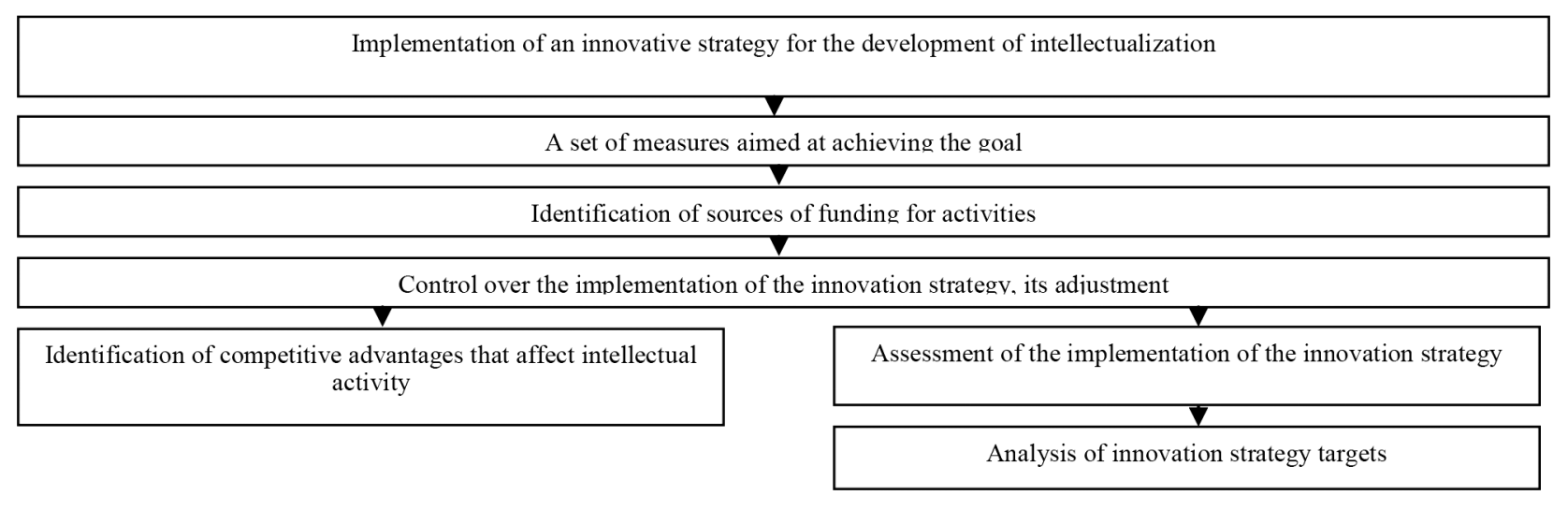

Fig. 3. Model of implementation of innovative strategy of development of machine-building enterprises

Using the results of the stages of strategic analysis and scenarios of innovative development by means of matrices of pairwise comparisons of criteria allows calculating their most probable state. It uses a list of factors (Fig. 4) that have the greatest impact on the future. For this, the comparison of integrated assessments by stages of development is made, as well as monitoring of the effectiveness of the implementation of innovative strategies for the growth of machine-building enterprises. A nine-point scale of relative importance, developed by T. Saati, was used to make subjective pairwise comparisons, which allows setting the weight of each of the criteria.

The further process is to conduct a pairwise comparison of strategies and identify priorities for each group of factors. The calculation of priorities is based on the compilation of matrices on the number of groups of factors that have a dimension according to the number of groups of strategic landmarks.

Results. We form matrices of pairwise comparison, which is carried out in two steps. In the first step, twenty respondents are selected from among the management staff of machinebuilding enterprises that meet the following qualities: having experience in decision-making in matters of economic security; currently working at machine-building enterprises. The second step is a pairwise comparison of factors by compiling a matrix of pairwise comparisons and determining the degree of their impact on the process of choosing an innovative strategy for enterprise growth. Pairwise comparison of factors relative to each other is based on a scale of evaluative judgments about the relative importance of factors [19,20].

We assess the intellectual capital of machine-building enterprises on the basis of the suggested algorithm.

Table 3 shows the normalized values of the components of the intellectual capital of machine-building enterprises for the period of 2017-2019.

The integrated valuation factor of human capital according to Table 3 is as follows

$$
I_{h c}=0.455+0.387 \cdot X_{1}-0.132 \cdot X_{2}-0.005 \cdot X_{3}+0.209 \cdot X_{4} \text {. }
$$

The integrated valuation ratio of organizational capital is as follows

$$
I_{o c}=0.293+0.303 \cdot X_{1}+0.275 \cdot X_{2}+0.007 \cdot X_{3}+0.0171 \cdot X_{4} .
$$

The integrated valuation ratio of structural capital is as follows

$$
I_{s c}=0.238+0.364 \cdot X_{1}+0.180 \cdot X_{2}+0.158 \cdot X_{3} .
$$

Table 4 shows the results of the calculation of the integrated coefficient of assessment of intellectual capital of machinebuilding enterprises.

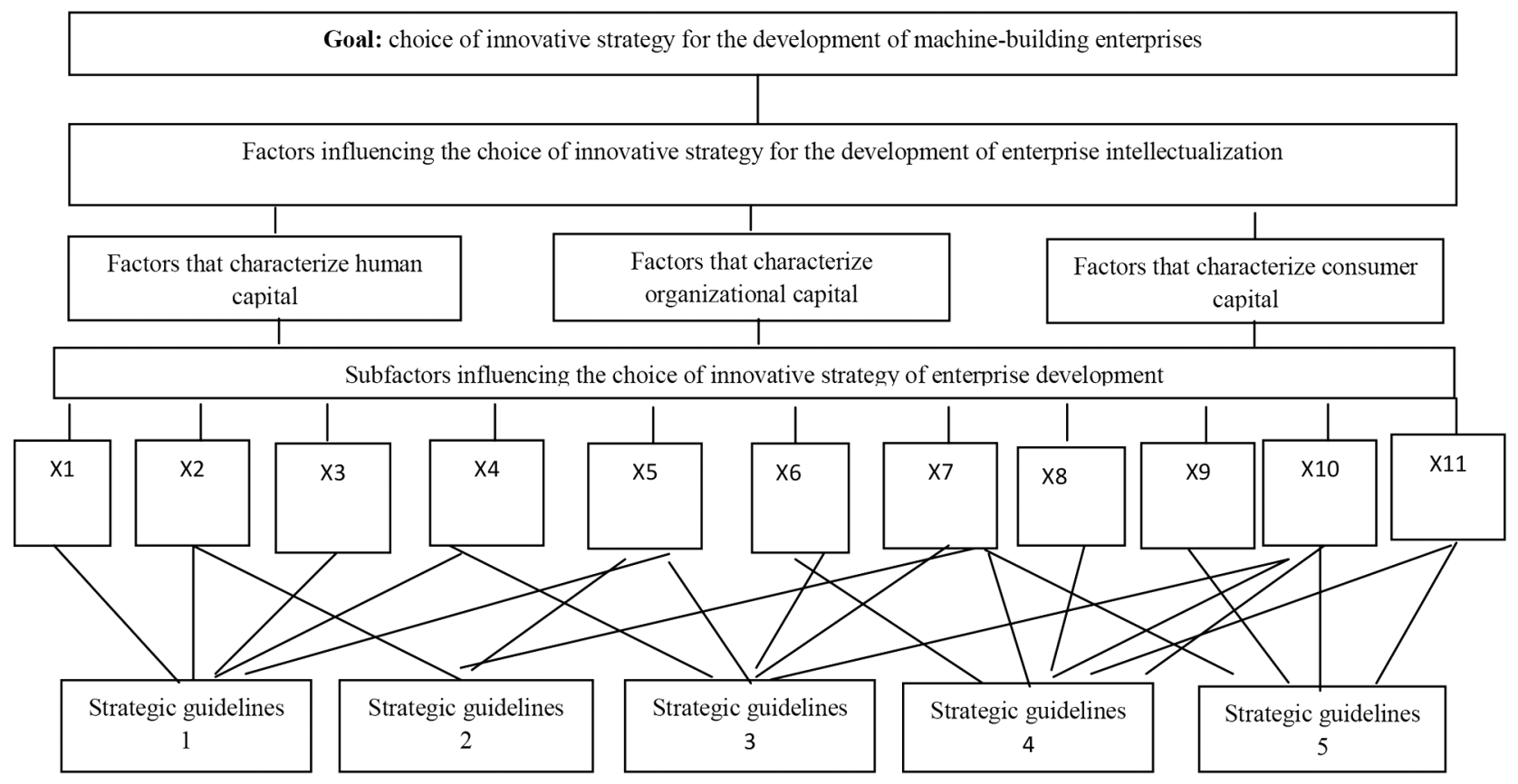

Fig. 4. Decomposition of the process of choosing an innovative strategy for the growth of machine-building enterprises in the hierarchy of goals 
Normalized values of the components of intellectual capital of machine-building enterprises

\begin{tabular}{|c|c|c|c|}
\hline Indicators & 2017 & 2018 & 2019 \\
\hline \multicolumn{4}{|l|}{ NKMZ PJSC } \\
\hline \multicolumn{4}{|l|}{ Human capital } \\
\hline Staff turnover ratio $(\mathrm{X} 1)$ & 0.013 & 0.015 & 0.020 \\
\hline The share of wage costs in the operating costs of the enterprise (X2) & 0.11 & 0.15 & 0.09 \\
\hline The share of workers with university degrees in the average number of staff (X3) & 0.46 & 0.55 & 0.65 \\
\hline Employee development index (X4) & 0.09 & 0.11 & 0.15 \\
\hline \multicolumn{4}{|l|}{ Organizational capital } \\
\hline Frame Stability Index (X5) & 0.81 & 0.82 & 0.83 \\
\hline Coefficient of research intensity $(\mathrm{R} \& \mathrm{D})(\mathrm{X} 6)$ & 0.015 & 0.017 & 0.011 \\
\hline Coefficient of intellectual intensity (X7) & 0,02 & 0.021 & 0.018 \\
\hline Computer service factor $(\mathrm{X} 8)$ & 75.11 & 77.08 & 85.47 \\
\hline \multicolumn{4}{|l|}{ Consumer capital } \\
\hline Number of signed contracts (X9) & 15 & 18 & 20 \\
\hline Market share, $\%(\mathrm{X} 10)$ & 15 & 16 & 17 \\
\hline Product Competitiveness Index (X11) & 0.75 & 0.81 & 0.82 \\
\hline \multicolumn{4}{|c|}{ PJSC "Druzhkivskyi Metal Products Plant" } \\
\hline \multicolumn{4}{|l|}{ Human capital } \\
\hline Staff turnover ratio $(\mathrm{X} 1)$ & 0.015 & 0.020 & 0.025 \\
\hline The share of wage costs in the operating costs of the enterprise (X2) & 0.09 & 0.05 & 0.03 \\
\hline The share of workers with university degrees in the average number of staff ( (X3) & 0.018 & 0.015 & 0.013 \\
\hline Employee development index (X4) & 0.010 & 0.012 & 0,011 \\
\hline \multicolumn{4}{|l|}{ Organizational capital } \\
\hline Frame Stability Index (X5) & 0.73 & 0.71 & 0.75 \\
\hline Coefficient of research intensity $(\mathrm{R} \& \mathrm{D})(\mathrm{X} 6)$ & 0.014 & 0.011 & 0.017 \\
\hline Coefficient of intellectual intensity (X7) & 0.017 & 0.013 & 0.015 \\
\hline Computer service factor $(\mathrm{X} 8)$ & 60.28 & 62.14 & 68.44 \\
\hline \multicolumn{4}{|l|}{ Consumer capital } \\
\hline Number of signed contracts (X9) & 10 & 18 & 21 \\
\hline Market share, $\%(\mathrm{X} 10)$ & 10 & 12 & 9 \\
\hline Product Competitiveness Index (X11) & 0.65 & 0.78 & 0.61 \\
\hline \multicolumn{4}{|c|}{ PJSC "Enerhomashspetsstal” } \\
\hline \multicolumn{4}{|l|}{ Human capital } \\
\hline Staff turnover ratio $(\mathrm{X} 1)$ & 0.015 & 0.018 & 0.022 \\
\hline The share of wage costs in the operating costs of the enterprise (X2) & 0.06 & 0.05 & 0.04 \\
\hline The share of workers with university degrees in the average number of staff ( (X3) & 0.52 & 0.59 & 0.67 \\
\hline Employee development index (X4) & 0.04 & 0.05 & 0.08 \\
\hline \multicolumn{4}{|l|}{ Organizational capital } \\
\hline Frame Stability Index (X5) & 0.75 & 0.78 & 0.68 \\
\hline Coefficient of research intensity (R\&D) (X6) & 0.09 & 0.08 & 0.05 \\
\hline Coefficient of intellectual intensity (X7) & 0.05 & 0.03 & 0.02 \\
\hline Computer service factor $(\mathrm{X} 8)$ & 75.32 & 78.45 & 80.23 \\
\hline \multicolumn{4}{|l|}{ Consumer capital } \\
\hline Number of signed contracts (X9) & 20 & 18 & 16 \\
\hline Market share, $\%(\mathrm{X} 10)$ & 12 & 9 & 14 \\
\hline Product Competitiveness Index (X11) & 0.82 & 0.74 & 0.83 \\
\hline \multicolumn{4}{|c|}{ LLC "Mining Machines - Druzhkivskyi Machine-Building Plant" } \\
\hline \multicolumn{4}{|l|}{ Human capital } \\
\hline Staff turnover ratio $(\mathrm{X} 1)$ & 0.022 & 0.025 & 0.030 \\
\hline
\end{tabular}


End of Table 3

\begin{tabular}{|l|c|c|c|}
\hline The share of wage costs in the operating costs of the enterprise (X2) & 0.08 & 0.07 & 0.05 \\
\hline The share of workers with university degrees in the average number of staff ( (X3) & 0.59 & 0.61 & 0.74 \\
\hline Employee development index (X4) & 0.02 & \multicolumn{2}{|c|}{0.018} \\
\hline Organizational capital & \multicolumn{3}{|c|}{0.017} \\
\hline Frame Stability Index (X5) & 0.67 & 0.71 & 0.68 \\
\hline Coefficient of research intensity (R\&D) (X6) & 0.014 & 0.013 & 0.011 \\
\hline Coefficient of intellectual intensity (X7) & 0.014 & 0.018 & 0.016 \\
\hline Computer service factor (X8) & 68.21 & 59.88 & 67.02 \\
\hline Consumer capital & & \multicolumn{3}{|c|}{} \\
\hline Number of signed contracts (X9) & 2 & 4 & 3 \\
\hline Market share, \% (X10) & 8 & 6 & 9 \\
\hline Product Competitiveness Index (X11) & 0.58 & 0.47 & 0.63 \\
\hline
\end{tabular}

Table 4

The value of the integrated coefficient of assessment of intellectual capital of machine-building enterprises

\begin{tabular}{|c|c|c|c|}
\hline Indicators & 2017 & 2018 & 2019 \\
\hline \multicolumn{4}{|c|}{ NKMZ PJSC } \\
\hline Integral valuation factor of human capital & 0.54 & 0.79 & 0.75 \\
\hline Integral coefficient of organizational capital valuation & 0.85 & 0.89 & 0.95 \\
\hline Integral structural capital valuation coefficient & 0.76 & 0.85 & 0.84 \\
\hline Integral intellectual capital valuation factor & 0.74 & 0.84 & 0.84 \\
\hline \multicolumn{4}{|c|}{ PJSC “Druzhkivskyi Metal Products Plant” } \\
\hline Integral valuation factor of human capital & 0.51 & 0.57 & 0.65 \\
\hline Integral coefficient of organizational capital valuation & 0.45 & 0.56 & 0.51 \\
\hline Integral structural capital valuation coefficient & 0.54 & 0.78 & 0.71 \\
\hline Integral intellectual capital valuation factor & 0.50 & 0.63 & 0.62 \\
\hline \multicolumn{4}{|c|}{ PJSC "Enerhomashspetsstal” } \\
\hline Integral valuation factor of human capital & 0.93 & 0.89 & 0.78 \\
\hline Integral coefficient of organizational capital valuation & 0.74 & 0.80 & 0.88 \\
\hline Integral structural capital valuation coefficient & 0.83 & 0.71 & 0.80 \\
\hline Integral intellectual capital valuation factor & 0.83 & 0.80 & 0.82 \\
\hline \multicolumn{4}{|c|}{ LLC "Mining Machines - Druzhkivskyi Machine-Building Plant" } \\
\hline Integral valuation factor of human capital & 0.34 & 0.44 & 0.40 \\
\hline Integral coefficient of organizational capital valuation & 0.44 & 0.30 & 0.43 \\
\hline Integral structural capital valuation coefficient & 0.32 & 0.28 & 0.38 \\
\hline Integral intellectual capital valuation factor & 0.36 & 0.33 & 0.40 \\
\hline
\end{tabular}

The obtained results show that the enterprises of PJSC NKMZ and PJSC "Enerhomashspetsstal" have a moderate growth of intellectual capital, which is characterized by a strategy of innovative development, namely - a strategy of renewal. The enterprise of PJSC "Druzhkivskyi Metal Products Plant" is characterized by a slow growth of intellectual capital, which is characterized by a strategy of innovative development - a strategy of development. The company LLC "Mining Machines - Druzhkivskyi Machine-Building Plant" has a level of low growth of intellectual capital, this level corresponds to the strategy of innovative development - the strategy of reorganization.

In order to determine the vector of global priorities (Table 5) in the matrix, the local priorities inherent in each alter-

Table 5

Vectors of global priorities of the five innovative development strategies

\begin{tabular}{|l|c|c|c|c|c|c|}
\hline \multicolumn{1}{|c|}{ Criterion } & Weight & Strategy 1 & Strategy 2 & Strategy 3 & Strategy 4 & Strategy 5 \\
\hline Human capital & 0.493 & 0.431 & 0.286 & 0.159 & 0.078 & 0.046 \\
\hline Consumer capital & 0.196 & 0.156 & 0.120 & 0.322 & 0.171 & 0.241 \\
\hline Organizational capital & 0.311 & 0.250 & 0.162 & 0.430 & 0.071 & 0.100 \\
\hline Overall score & 1.000 & 0.257 & 0.194 & 0.285 & 0.133 & 0.131 \\
\hline
\end{tabular}


native are multiplied by the priority of each criterion, and the result is summed.

Based on the results of calculations obtained using the method of analysis of hierarchies (MAI), strategy 3, namely the "Development Strategy" were the most acceptable for machine-building enterprises.

Conclusions. In the process of research, the model of estimation of intellectual capital of the enterprise on the basis of use of the correlation-regressive analysis and a methodical approach of formation and a choice of strategy of innovative development of the machine-building enterprises in the conditions of digitalization was developed.

It is proved that the assessment of intellectual capital is carried out on such structural elements as: human, organizational and consumer capital.

Each of the above elements can be assessed using indicators that characterize the characteristics of the intellectual capital of the enterprise in terms of digitalization.

Methodical recommendations of formation of innovative strategy of development of a machine-building enterprise in the conditions of digitalization are offered, defining the purposes, principles and algorithm of formation of innovative strategy of growth of machine-building enterprise, which includes, in addition to the traditional stages, the stage of strategic choice, which consists in the development of alternative strategies taking into account the strategy horizon, the assessment of the base platform, identifying types of innovations, objects of strategy and evaluation of possible target results. This will allow the most reasonable choice of innovation strategy of the machine-building enterprise

The introduction of a methodological approach to the choice of strategy will allow the company to assess and increase the level of innovation capital, which will lead to increased innovation activity of the enterprise and its economic growth. Involvement of leading specialists in the development and implementation of innovations will contribute to the continuous development of the enterprise in the direction of innovation, increase its intellectual capital, added value, capitalization and competitiveness.

The practical implementation of the suggested methodological approach was carried out on the example of machinebuilding enterprises. In the course of the research, it will be established that the "development strategy" turned out to be the most acceptable for their development.

Prospects for further research include the development of a model for assessing the impact of investment activities of enterprises on sustainable development of the region, taking into account quantitative and qualitative indicators of intellectualization processes.

\section{References.}

1. Nambisan, S., Lyytinen, K., Majchrzak, A., \& Song, M. (2017). Digital innovation man-agement: Reinventing innovation management research in a digital world. MIS Quarterly, 41(1). 223. https:// doi.org/10.25300/MISQ/2017/41:1.03.

2. Foss, N.J., \& Saebi, T. (2017). Fifteen years of research on business model innovation: how far have we come, and where should we go? Journalof Management, 43(1),200.https://doi.org/10.1177/0149206316675927. 3. Bryukhovetskaya, N. Ye., \& Korytko, T. Yu. (2017). Innovative development as a factor of competitiveness in the face of external constraints. Strategy and mechanisms for regulating industrial development, 12. Retrieved from http://nbuv.gov.ua/UJRN/sim 201720174.

4. Nitsenko, V. S., \& Havrysh, V. I. (2016). Enhancing the stability of a vertically integrated agro-industrial companies in the conditions of uncertainty. Actual problems of economics, 10(184), 167-172.

5. Loebbecke, C., \& Picot, A. (2015). Reflections on societal and business model transformation arising from digitization and big data analytics: a research agenda, Journal of Strategic Information Systems, 24(3), 149. https://doi.org/10.1016/j.jsis.2015.08.002.

6. Paulus-Rohmer, D., Schatton, H., \& Bauernhansl, T. (2016). Ecosystems, strategy and business models in the age of digitization - how the manufacturing industry is going to change its logic. Procedia CRIP, 57, 8. https://doi.org/10.1016/j.procir.2016.11.003.
7. Bryl, I. (2018). The intellectual capital as the value added factor on ensuring increase in investment activity in the state. Economic Bulletin of Donbass, 2, 191-200. Retrieved from http://nbuv.gov.ua/UJRN/ ecvd $2018 \quad 231$.

8. Nitsenko, V., Nyenno, I., Kryukova, I., Kalyna, T., \& Plotnikova, M. (2017). Business model for a sea commercial port as a way to reach sustainable development goals. Journal of Security and Sustainability Issues, 7(1), 155-166. https://doi.org/10.9770/jssi.2017.7.1(13). 9. Kita, P., \& Simberová, I. (2018). An overview of business models in the Czech chemical industry: A sustainable multiple value creation perspective. Entrepreneurship and Sustainability Issues, 6(2), 662-676. https://doi.org/10.9770/jesi.2018.6.2(14).

10. Andriushchenko, K., Tepliuk, M., Sahaidak, M., Kartashov, E., Pivovarov, K., Kutashev, I., Voronina, Y., ..., \& Kuchai, O. (2020). Management of the mental resources of the enterprise. International Journal of Management, 11(6), 52-64. http://doi.org/10.34218/ IJM.11.6.2020.005.

11. Nitsenko, V., Kotenko, S., Hanzhurenko, I., Mardani, A., Stashkevych, I., \& Karakai, M. (2020). Mathematical Modeling of Multimodal Transportation Risks. In Ghazali R., Nawi N., Deris M., Abawajy J. (eds) Recent Advances on Soft Computing and Data Mining. SCDM 2020. Advances in Intelligent Systems and Computing, (pp. 439-447). Springer: Cham. https://doi.org/10.1007/978-3-030-36056-6 41.

12. Krichevsky, S. (2020). Creation of a "Cosmic" Human: Ideas, Technologies, Projects, Experience, Risks, Limitations, and Prospects. Future Human Image, 13, 32-45. https://doi.org/10.29202/fhi/13/4 13. Petrova, M., Koval, V., Tepavicharova, M., Zerkal, A., Radchenko, A., \& Bondarchuk, N. (2020). The interaction between the human resources motivation and the commitment to the organization. Journal of Security and Sustainability Issues, 9(3), 897-907. https://doi. org/10.9770/jssi.2020.9.3(15)

14. Vătămănescu, E.M., Gorgos, E.A., Ghigiu, A. M., \& Monica Pătrut, M. (2019). Bridging intellectual capital and SMEs internationalization through the lens of sustainable competitive advantage: A systematic literature. Sustainability, 11(1), 1-22. https://doi.org/10.3390/ su11092510.

15. Chukurna, O., Nitsenko, V., Kralia, V., Sahachko, Y., Morkunas, M., \& Volkov, A. (2019). Modelling and Managing the Effect of Transferring the Dynamics of Exchange Rates on Prices of MachineBuilding Enterprises in Ukraine. Polish Journal of Management Studies, 19(1), 117-129. https://doi.org/10.17512/pjms.2019.19.1.09.

16. Xu, J., \& Wang, B. (2019). Intellectual capital performance of the textile industry in emerging markets: A comparison with China and South Korea. Sustainability, 11(1), 1-16. https://doi.org/10.3390/ su11236582.

17. Raišienè, A.G., Yatsenko, O., Nitsenko, V., Karasova, N., \& Vojtovicova, A. (2019). Global dominants of Chinese trade policy development: Opportunities and threats for cooperation with Ukraine. Journal of International Studies, 12(1), 193-207. https://doi. org/10.14254/2071-8330.2019/12-1/13.

18. Latysheva, O., Rovenska, V., Smyrnova, I., Nitsenko, V., Balezentis, T., \& Streimikiene, D. (2020). Management of the sustainable development of machine-building enterprises: a sustainable development space approach. Journal of Enterprise Information Management, 34(1), 328-342. https://doi.org/10.1108/JEIM-12-2019-0419.

19. Bezzubov, D., \& Pravotorova, O. (2020). The Impact of Transnational Corporations on the Regulatory Framework for the World Market for Space Services and Technologies. Advanced Space Law, 6, 4-12. https://doi.org/10.29202/asl/6/1.

20. Filipchuk, V. (2019). Information and Digital Toolset in a Fight against Liberal Democracy and Values of Open Society. Ukrainian Policymaker, 5, 34-43. https://doi.org/10.29202/up/5/4

\section{Стратегія інноваційного розвитку підприємства на основі оцінки його інтелектуального капіталу}

\section{T. Ю. Коритько ${ }^{1}$, I. В. Бриль ${ }^{1}$, С. Т. Пілецька ${ }^{2}$ O. В. Ареф'єва ${ }^{2}$, C. О. Ареф'є ${ }^{3}$}

1 - Інститут економіки промисловості України, м. Київ, Україна, e-mail: taniakorytko@gmail.com

2 - Національний авіаційний університет, м. Київ, Україна

3 - Національний університет технології та дизайну, м. Київ, Україна 
Мета. Удосконалення стратегії інноваційного розвитку промислових підприємств на основі оцінки інтелектуального капіталу підприємства й розробка етапів вибору стратегії на основі використання методу аналізу ієрархій.

Методика. У ході дослідження був використаний набір загальних і спеціальних методів пізнання: контентаналіз, логічне узагальнення, кількісне та якісне порівняння, метод головних компонент і систематизація.

Результати. Запропонована оцінка інтелектуального капіталу підприємства й методичний підхід до формування та вибору його стратегії інноваційного розвитку в умовах цифровізації дозволяє проаналізувати кількісні показники структурних елементів інтелектуального капіталу, визначити стан і рівень розвитку кожного окремого елемента. Це дозволяє підвищити ефективність формування та реалізації стратегії інноваційного розвитку підприємства.

Наукова новизна. У ході дослідження розроблено алгоритм інтегральної оцінки інтелектуального капіталу промислових підприємств. Він дозволив оцінити рівень інтелектуального капіталу, етапи формування інноваційної стратегії розвитку, що виступають інформаційно- аналітичним інструментом для розробки варіантів стратегічного розвитку промислових підприємств. Модель реалізації інноваційної стратегії розвитку промислових підприємств забезпечує вибір інноваційної стратегії розвитку промислових підприємств. Метод аналізу ієрархій дозволив виявити найбільш ефективну для промислових підприємств стратегію інноваційного розвитку.

Практична значимість. Результати дослідження можуть бути використані практиками, ученими, державними службовцями (Міністерства розвитку економіки, торгівлі й сільського господарства та його структурні підрозділи, органи місцевого самоврядування у сфері економіки) для розробки та впровадження стратегії інноваційного розвитку, а також для розробки заходів, що сприятимуть постійному розвитку підприємства в інноваційному напрямі, підвищенню його інтелектуального капіталу, доданої вартості, капіталізації та рівня конкурентоспроможності.

Ключові слова: промислове підприємство, інноваційний розвиток, інтелектуальний капітал, цифровізація

Recommended for publication by N. Kasianova, Doctor of Economic Sciences. The manuscript was submitted 20.11.20. 